\title{
Lift Technique for Fistula in ANO with Redefined Criteria - A Step towards Better Outcome.
}

\author{
Dr. Tanweerul Huda (MBBS), Dr Mhaske Ashok (MS) \\ Department of Surgery, People's College of Medical Sciences \& Research Centre, Bhopal, India. \\ Address for correspondence: Dr Ashok Mhaske, Vice Dean, Professor \& Head-Surgery, People's College of \\ Medical Sciences \& Research Centre, Bhopal, India.
}

Objective: To reemphasize LIFT technique for fistula in ano with redefined inclusion and exclusion criteria developed by Thai surgeon Arun Rojanasakul \& to standardize the procedure for our setting. Material \& Method: A prospective observational study in 32 fistula in ano patients treated by LIFT technique from Sept 2011 to March 2013.

Result: Fistula in ano healed primarily in all 32 patients as inclusion and exclusion criteria were strictly observed. Average healing time was around 4-6 weeks. 1 fistula took around 8wks to heal as the patient had immunocompromised status.

Conclusion: Results of standardized lift technique are impressive \& this technique can be implemented widely for treatment of fistula in ano provided inclusion \& exclusion criteria are strictly observed.

Keyword: LIFT TECHNIQUE, FISTULA IN ANO, ARUN ROJANASAKUL.

\section{Introduction}

Anal fistula is an abnormal connection between the epithelialized surface of anal canal and (usually) the perianal skin [1]. Fistula in ano does not heal spontaneously due to fecal particles entering internal opening causing infection \& the intersphincteric tract is compressed between the internal \& external sphincter causing a closed septic foci [1]. Surgical techniques used are - Lay-open of fistula-in-ano, cutting seton, seton stitch, fibrin glue injection, fistula plug, endorectal advancement flap, vaaft etc. [1].

Complications are - recurrence, incontinence, anal stenosis etc. [1]. Recurrence rate of lay open of fistulotomy is around $2-9 \%$, with functional impairment of from $0-17 \%[1]$. Seton use has a recurrence rate of 0 $8 \%$.Incontinence rates of $2-26 \%$.Endorectal advancement flap has healing rate of $98 \%$ with minor \& major incontinence of $31 \& 12 \%$.Direct closure of internal opening has a $22.5 \%$ recurrence rate $\& 6 \%$ minor incontinence[1].

Healing rate of debridement with fibrin glue injection was from $14-60 \%$ \& incontinence was not reported [1]. Fistula plug has a failure rate of around 13\% [1].

LIFT is a new technique of intersphincteric fistula-in-ano tract ligation developed by Thai surgeon Arun Rojanasakul for saving the anal sphincter during fistulectomy.

Our study aimed to improvise effectiveness of this technique with redefined inclusion and exclusion criteria.

\section{Materials \& Methods}

After screening with predefined criteria all 32 fistula in ano patients (26 males, 6 females) reported at our hospital during period from Sept 2011 to March 2013 were operated using standard LIFT technique. Transsphincteric fistulas in ano were selected. All patients were continent \& had no history of any chronic disease. All patients were precounselled regards the procedure $\&$ written consent taken.

\section{RE-DEFINED INCLUSION CRITERIA}

1. Age (27-56) years.

2. Proved cases of transsphincteric low anal fistula without co- morbid conditions.

3. Maturation of tract.

4. Antibiotic cover preoperatively for three days - 3rd generation cephalosporins.

\section{RE-DEFINED EXCLUSION CRITERIA}

1. Patients with granulomatous diseases

2. Anorectal abscess

\section{Assessment of wound healing [1]}


Grade 1: Complete epithilization of wound.

Grade 2: Healing wound with granulation.

Grade 3: Granulation with purulent discharge.

Grade 4: Non healing, not healed at 10 wks.

Assessment of clinical continence [1]

Category A: Continent of solid \& liquid stools \& flatus (i.e. normal continence)

Category B: Continent of solid \& usually liquid stools but not flatus (no fecal leakage)

Category C: Acceptable continence for solid stool but no control over liquid stool or flatus.

Category D: Continued fecal leakage.

\section{Results}

Data of 32 patients ( 26 males, 6 females), aged between 25 to 65 yrs. were analyzed. All patients had transphincteric fistulas. Mean length of hospital stay was 3-7 days. Mean healing time was 4wks (range from 26 wks.) Primary healing of intersphincteric incision healed in all patients. There was no change in continence status postoperatively (as intersphincteric plane was strictly adhered). No complications were observed except one (Details of complication in our study).

\section{Discussion}

Fistula in ano is known to have recurrences and incontinence $\&$ till date there is no single technique accepted for its treatment. Many techniques have been developed for treating fistula in ano like cutting Seton, Seton stitch, fibrin glue injection, fistula plug, endorectal advancement flap, anoderm island flap, vaaft technique etc.

Arun Rojanasakul developed this LIFT technique for treating fistula in ano \& saving the anal sphincter. Proposed advantages of LIFT technique are [1]:

1. Anal sphincter saving.

2. Minimal tissue injury leading to shorter healing time.

3. Small scar.

4. Can be done in previously operated patients.

5. Reoperation can be done after the procedure in case of recurrence.

Different studies have shown success rates of LIFT technique ranging from $63-94.4 \%$.

In our setup also the success rate was around $100 \%$ with redefined criteria.

Hence if the effectivity of the technique is to be improvised we feel after this study that strict adherence to redefined criteria is mandatory.

\section{Conclusion}

LIFT technique is indeed a sphincter saving technique for treating fistula in ano but we feel that its effectiveness will be improved if redefined inclusion \& exclusion criteria are strictly adhered to.

TABLE 1.Incidence of complications with LIFT technique:

\begin{tabular}{|l|l|l|}
\hline Complication & Rate & Remarks \\
\hline Recurrence & $17.5 \%$ & Mostly due to faulty technique. \\
\hline Anal Incontinence & $0 \%$ & $\begin{array}{l}\text { No change in anal continence if } \\
\text { intersphincteric plane adhered to. }\end{array}$ \\
\hline
\end{tabular}

TABLE 2. Various techniques - Comparative Chart

\begin{tabular}{|l|l|l|l|}
\hline Technique & Highlights & Success Rate & Complications \\
\hline Fistulotomy & Oldest technique & $\begin{array}{l}\text { Recurrence }(2 \%-9 \%) \\
\text { Incontinence }(0 \%-17 \%)\end{array}$ \\
\hline Cutting seton & $\begin{array}{l}\text { Mainly for low anal } \\
\text { fistulas }\end{array}$ & $0-58 \%$ & $\begin{array}{l}\text { Recurrence }(0-8 \%) \\
\text { Incontinence }(2-63 \%)\end{array}$ \\
\hline $\begin{array}{l}\text { Fibrin } \\
\text { Glue }\end{array}$ & $\begin{array}{l}\text { Conservative technique. } \\
\text { Useful in most fistulas }\end{array}$ & $14-60 \%$ & Recurrence $(20-83 \%)$ \\
\hline $\begin{array}{l}\text { Endorectal Advancement } \\
\text { flap }\end{array}$ & $\begin{array}{l}\text { Used for complex fistula } \\
\text { in ano. }\end{array}$ & $36.6 \%-98.5 \%$ & $\begin{array}{l}\text { Recurrence }(5-37 \%) \\
\text { Incontinence }(0-35 \%)\end{array}$ \\
\hline $\begin{array}{l}\text { Anodermal advancement } \\
\text { flap }\end{array}$ & $\begin{array}{l}\text { Used for complex fistula } \\
\text { in ano. }\end{array}$ & $\begin{array}{l}\text { Recurrence }(2-40 \%) \\
\text { Incontinence }(0-15 \%)\end{array}$ \\
\hline Fistula plug & $\begin{array}{l}\text { Can be used as a primary } \\
\text { treatment modality in } \\
\text { most fistulas. }\end{array}$ & $31-83 \%$ & Recurrence $(12-38 \%)$ \\
\hline
\end{tabular}


Lift Technique For Fistula In Ano With Redefined Criteria - A Step Towards Better Outcome.

TABLE 3. Comparative data of LIFT Technique at various centers.

\begin{tabular}{|l|l|l|}
\hline Study-Name & Success rate & Remarks \\
\hline $\begin{array}{l}\text { Rojanasakul et al. } \\
\text { (Thailand) }\end{array}$ & $94.4 \%$ & Novel sphincter saving technique \\
\hline $\begin{array}{l}\text { Shanwani et.al } \\
\text { (Malaysia) }\end{array}$ & $82 \%$ & $\begin{array}{l}\text { Safe \& Easy to perform with } \\
\text { good outcomes }\end{array}$ \\
\hline Bleier et. al (USA) & $63 \%$ & Large scale study warranted. \\
\hline
\end{tabular}

\section{References}

[1]. Rojanasakul A. LIFT Procedure: a simplified technique for fistula in ano. Tech coloproctol.2009; sep; 13(3):237-40. Epub 2009 Jul. 28.

[2]. Rojanasakul A, Pattanaarun J, Sahakitrungruang C, Tantiphlachiva K. Total anal sphincter saving technique for fistula- in- ano; the ligation of intersphincteric fistula tract. J Med Assoc Thai. 2007 mar; 90 (3):581-6.

[3]. Sangar P, MBBS, MS, Rojanasakul A. Fistula-in-ano: How I Do the LIFT Procedure. The Sri Lanka Journal of Surgery 2011; 29(2):97-99.

[4]. Peter J. Lunniss. LIFT procedure: a simplified technique for fistula-in-ano. Tech Coloproctol (2009) 13:241-242.

[5]. Mohammed Amir. Current Trends in Management of Fistula-in-Ano: Can We Minimize Recurrence? Journal of Surgery Pakistan (International) 16 (2) April - June 2011.

[6]. William h. Isbister. Fistula-in-ano. Aust. Nz. j. Surg. (1999) 69, 768-769.

[7]. Claudio Fucini, Jacopo Giani. Why do we have to review our experience in managing cases with idiopathic fistula-in-ano regularly? World J Gastroenterol 2011 July 28; 17(28): 3297-3299.

[8]. Whiteford MH, Kilkenny J III, Hyman N, Buie WD, Cohen J, Orsay C, et al. Practice parameters for the treatment of perianal abscess and fistula-in-ano (revised). Dis Colon Rectum 2005; 48: 1337-42.

[9]. Vasilevsky CA, Gordon PH. The incidence of recurrent abscesses or fistula-in-ano following anorectal suppuration. Dis Colon Rectum 1984; $27:$ 126-30.

[10]. Van Tets WF, Kuijpers HC. Continence disorders after anal fistulotomy. Dis Colon Rectum 1994; 37: $1194-7$.

[11]. Williams JG, MacLeod CA, Rothenberger DA, Goldberg SM. Seton treatment of high anal fistulae. Br J Surg 1991; 78: 1159-61.

[12]. Kee Ho Song. New Techniques for Treating an Anal Fistula. J Korean Soc Coloproctol 2012;28(1):7-12.

[13]. P. Meinero - L. Mori. Video-assisted anal fistula treatment (VAAFT): a novel sphincter-saving procedure for treating complex anal fistulas. Tech Coloproctol (2011) 15:417-422.

[14]. Garcia-Aguilar J, Belmonte C, Wong DW, Goldberg SM, Madoff RD. Cutting seton versus two-stage seton fistulotomy in the surgical management of high anal fistula. Br J Surg 1998; 85: 243-5.

[15]. Pearl RK, Andrews JR, Orsay CP, Weisman RI, Prasad ML, Nelson RL, et al. Role of the seton in the management of anorectal fistulas. Dis Colon Rectum 1993; 36: 573-7.

[16]. Isbister WH, Al Sanea N. The cutting seton: an experience at King Faisal Specialist Hospital. Dis Colon Rectum 2001; 44: 722-7.

[17]. Dziki A, Bartos M. Seton treatment of anal fistula: experience with a new modification. Eur J Surg 1998; $164: 543-8$.

[18]. Hamalainen KP, Sainio AP. Cutting seton for anal fistulas: high risk of minor control defects. Dis Colon Rectum 1997; 40: $1443-6$.

[19]. Van Tets WF, Kuijpers JH. Seton treatment of perianal fistula with high anal or rectal opening. Br J Surg 1995; 82: 895-7.

[20]. Kodner IJ, Mazor A, Shemesh EI, Fry RD, Fleshman JW, Birnbaum EH. Endorectal advancement flap repair of rectovaginal and other complicated anorectal fistulas. Surgery 1993; 114: 682-9.

[21]. Aguilar PS, Plasencia G, Hardy TG Jr, Hartmann RF, Stewart WR. Mucosal advancement in the treatment of anal fistula. Dis Colon Rectum 1985; 28: 496-8.

[22]. Schouten WR, Zimmerman DD, Briel JW. Transanal advancement flap repair of transsphincteric fistulas. Dis Colon Rectum 1999; 42: 1419-22.

[23]. Gustafsson UM, Graf W. Excision of anal fistula with closure of the internal opening: functional and manometric results. Dis Colon Rectum 2002; 45: 1672-8.

[24]. Kreis ME, Jehle EC, Ohlemann M, Becker HD, Starlinger MJ. Functional results after transanal rectal advancement flap repair of trans-sphincteric fistula. Br J Surg 1998; 85: 240-2.

[25]. Zimmerman DD, Briel JW, Gosselink MP, Schouten WR. Anocutaneous advancement flap repair of transsphincteric fistulas. Dis Colon Rectum 2001; 44: 1474-80.

[26]. Athanasiadis S, Helmes C, Yazigi R, Kohler A. The direct closure of the internal fistula opening without advancement flap for transsphincteric fistulas-in-ano. Dis Colon Rectum 2004; 47: 1174-80.

[27]. Abel ME, Chiu YS, Russell TR, Volpe PA. Autologous fibrin glue in the treatment of rectovaginal and complex fistulas. Dis Colon Rectum 1993; 36: 447-9. 